\title{
$\beta$ 型チタン合金の機械的性質亡疲れ強さ
}

Mecanical and Fatigue Properties of the Beta Titanium Alloy

\author{
小松 征 士* \\ Masashi KOMATSU
}

\section{1。まえがき}

チタンは僌く，耐食性が高いととから，航空機や宇宙 機器をはじめ化学工業・石油産業分野を中心に用いられ 研究されている．チタンがばね机利用された例はあまり

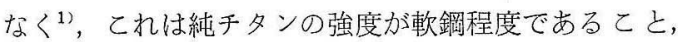
最も高い強度を有する $\beta$ 型チタン合金の研究が最近ま であまり進んでいないとと，さらにチタンが非常に高洒 であることなどに起因している.

とこではチタン合金の中で最も高い強度が得られる $\beta$ 型チタン合金をばね素材に取り上げ，機械的性質と疲れ 強さについて檢討してみた。

\section{2。供試材・試験片}

供試材の化学成分を表 1 亿示す. との合金はチタンに $15 \% \mathrm{Mo}, 5 \% \mathrm{Zr}, 3 \% \mathrm{Al}$, を加えた $\beta$ 型チタン合金 ${ }^{2}$ で $\mathrm{Mo}, \mathrm{Zr}$ の合金により高温でのみ安定な $\beta$ 相を常温 て準安定 $\beta$ 相とし，Al により $\alpha$ 相の強化とぜい化防 止を計ったものである. 強度は溶体化処理後の析出硬化 処理により $\alpha, w$ 粒子の析出により強化される.

供試材はビレットを $880 \sim 600^{\circ} \mathrm{C}$ で $9.5 \phi$ の丸棒に熱 間圧延し，溶体化処理 $\left(785^{\circ} \mathrm{C} \times 1 \mathrm{hr}\right.$, 水冷), 矯正した

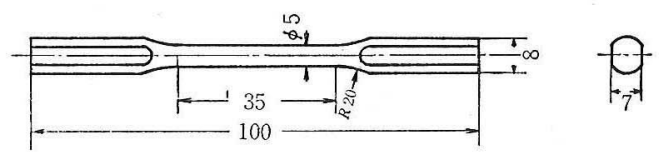

図 1 就験出

後表面研削により $8.0 \phi$ の丸棒としたもので，これより 引張試験片，ねじり，疲れ試験片を機械加工に上り製作 した．各試験片は図 1 亿示す同一形状の試験片を用い， 有効径を $5.0 \phi$ とした。 引張試験片は JIS $14 \mathrm{~A}$ 号, 疲 れ試駼片は JIS Z 2273 に基づき製作し，析出硬化処理 は $500^{\circ} \mathrm{C} \times 16 \mathrm{hr}$ ，空冷により大気中にて行い，表面に形 成された酸化皮膜は研摩紙によりそれぞれの試験前に除 去しておいた，写真 1 亿試験片横断面の顕微鏡組織写真 を示す、試験片の結晶粒度は粗く，粒度番号 ASTM No. 2.5〜3 であった.

\section{3. 試験方法}

3.1 機械的性質

機械的性質として引張試験とねじり試験を，溶体化試 験片, 析出硬化試験片について行った. 引張試験はイン ストロン型万能引張圧縮試験機により, 引張強さ・のび ・絞りを求めた，㸚じり試験は $5 \mathrm{~kg}-\mathrm{m}$ 精密ねじり試験 表 1 供試材化学成分

(\%)

\begin{tabular}{|c|c|c|c|c|c|c|c|c|c|c|}
\hline & & & Mo & $\mathrm{Zr}$ & $\mathrm{Al}$ & $\mathrm{Fe}$ & C & 0 & $\mathrm{H}$ & $\mathrm{N}$ \\
\hline & 試 & 材 & 14.97 & 5.04 & 2. 93 & 0.047 & 0.006 & 0.1650 & 0.0124 & 0.0129 \\
\hline
\end{tabular}

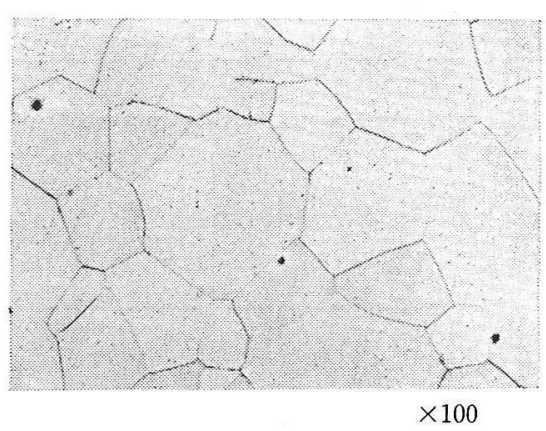

溶体化試験片

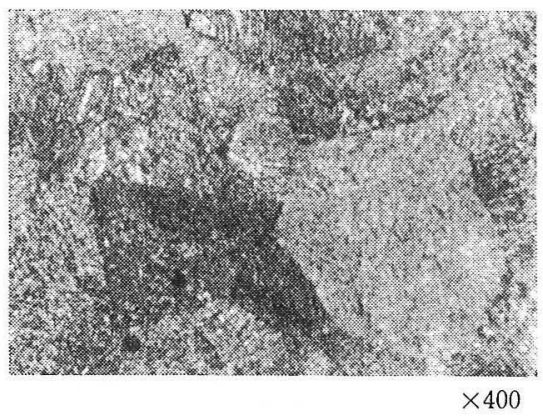

析出硬化試験片

写真 1 試験片顕微鏡組織（硝酸フッ化水素水溶液腐食）

*日本発条株式会社 


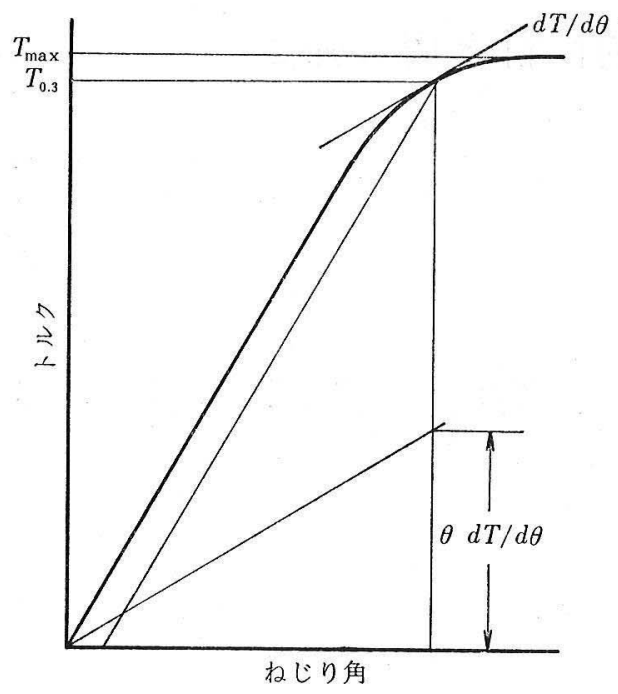

图 2 ねじり強さの求め方

機により最大せん断応力, 降伏応力 $(\gamma=0.3)$, 横弾性 係数を求めた，㸚じり試験に打りる各值は図 2 亿示可記 録紙により $T_{\max }, T_{0.3}, \theta d T / d \theta$ を求め次式により算 出した。

$$
\begin{array}{ll}
\text { 最大せん断応力 } & \left(\tau_{\max }\right)=12 T_{\max } / \pi D^{3} \\
\text { 降伏応力 } & \left(\tau_{0.3}\right)=4\left(3 T_{0.3}+\theta d T / d \theta\right) / \pi D^{3} \\
\text { 横弾性係数 } & (G)=T / \theta \times 32 l / \pi D^{4}
\end{array}
$$

$(D:$ 試験片直径 $l:$ 試験片長さ $\theta:$ 㸚じり角)

なお，横弾性係数測定の場合はツカミ部での誤差をな くすため，標点部に鏡を取り付け，鏡装置によりねじり 角を求めた。

\section{2 疲机特性}

疲れ試験は $4 \mathrm{~kg}-\mathrm{m}$ 小型シェンク疲れ試験機を用い, 片振り之部分片振りでねじり疲れ試験を行った．筫荷応 力は試験機に取り付けられたダイヤルゲージより，トル クを求ぬ設定し, 繰返し速度は 3,000 r.p. m, 疲れ限度 は $5 \times 10^{6}$ 回の繰返数に耐え得る応力とした。なお，部 分片振りの試験では平均応力を, 溶体化試験片の場合 35 $\mathrm{kg} / \mathrm{mm}^{2}$, 析出硬化試験片の場合 $45 \mathrm{~kg} / \mathrm{mm}^{2}$ 目標上 した。
4. 結
果

4.1 機械的性翼
引張試験，ねじり試騟の結果を表 2 亿示す、引張試験 ではのび計が付汀られなかったため，引張強さ・のび・ 絞りのみを求めた. 析出硬化処理に上り引張強さは約 15 $\%$ 向上し， $125 \mathrm{~kg} / \mathrm{mm}^{2}$ ，㸚じり強さは約 $30 \%$ 向上し， 最大せん断応力は $83.8 \mathrm{~kg} / \mathrm{mm}^{2}$ であった。 反面, 析出 硬化処理により延性が低下し，特に絞りは局部絞りが認 められず，カップアンドコーン型の破壊様式は示さなか った．写真 2 亿引張試験後の破断状沉を示す.

故じり特性は溶体化状龍で引張強さの約 $60 \%$ の降伏 応力を有し，析出硬化処により $65 \%$ にまで向上した. また，最大せん断応力に対する降伏比は析出硬化前後之 あに 96〜97\% 程度であった。

横弾性係数は析出硬化前後で大きく変化し, 硬化後平 均 $4,024 \mathrm{~kg} / \mathrm{mm}^{2}$ と㧍よそ $25 \%$ 大学くなっている.

なお，各値の標準偏差を参考に求めたが，どの值も析 出硬化処理によりバラッキが小さくなる。

\section{2 疲れ特性}

ねじり疲れ試験を図 $3 ・ 4$ の S-N 線図に示す。また， 疲れ限度線四を図 5 に示す，析出硬化処理により疲れ限 度は向上し，片振りでは $\pm 13 \mathrm{~kg} / \mathrm{mm}^{2}$ から $\pm 19 \mathrm{~kg} /$ $\mathrm{mm}^{2}$ にまで, 部分片振りでは $10 \mathrm{~kg} / \mathrm{mm}^{2}$ から $15 \mathrm{~kg} /$ $\mathrm{mm}^{2}$ にまで向上した．乙の結果より，析出硬化処理後 の最大許容応力は片振りで約 $38 \mathrm{~kg} / \mathrm{mm}^{2}$, 部分片振り では拉よそ $60 \mathrm{~kg} / \mathrm{mm}^{2}$ ほどであった，疲学クラックは どの場合む線軸にほぼ $45^{\circ}$ 万向に進み，破面は非常に粗 かった。

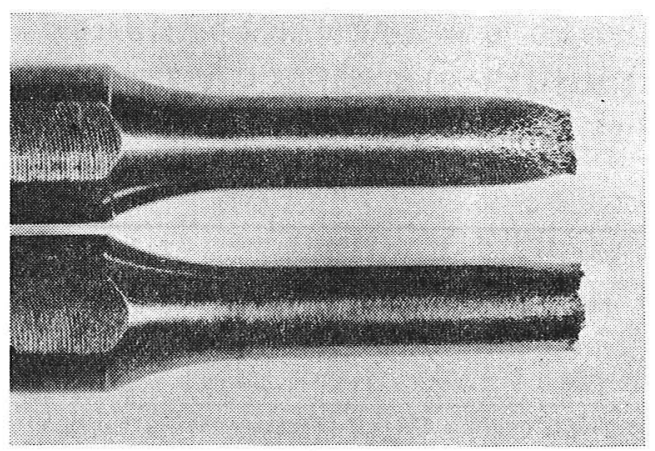

上）溶体化試験片

下）析出硬化試験片

\begin{tabular}{|c|c|c|c|c|c|c|c|c|}
\hline & & $\begin{array}{l}\text { 引䛗張 強 } \\
\left(\mathrm{kg} / \mathrm{mm}^{2}\right) \\
\end{array}$ & ${ }_{(\%)}^{\mho \mho}$ & 絞 $(\%)^{\natural}$ & $\begin{array}{l}\text { 最大せん断応 } \\
\text { 力 }\left(\mathrm{kg} / \mathrm{mm}^{2}\right)\end{array}$ & $\begin{array}{c}\text { ねじり降代点 } \\
\left(\mathrm{kg} / \mathrm{mm}^{2}\right)\end{array}$ & $\begin{array}{l}\text { 横弾性係数 } \\
\left(\mathrm{kg} / \mathrm{mm}^{2}\right)\end{array}$ & 試暍片数 \\
\hline 溶 & $\begin{array}{l}\text { 体 华 } \\
\text { 験 片 }\end{array}$ & $\begin{array}{r}108.6 \\
(2.57)\end{array}$ & 14.2 & 61.1 & $\begin{array}{r}64.2 \\
(2.27) \\
\end{array}$ & $\begin{array}{r}61.7 \\
(1.47)\end{array}$ & $\begin{array}{r}3,219 \\
(98.8)\end{array}$ & 8 \\
\hline $\begin{array}{l}\text { 慗 } \\
\text { 試 }\end{array}$ & $\begin{array}{c}\text { 出硬 稚 } \\
\text { 片 }\end{array}$ & $\begin{array}{l}125.2 \\
(2.15)\end{array}$ & 11.8 & 17.3 & $\begin{array}{r}83.8 \\
(1.13)\end{array}$ & $\begin{array}{r}81.2 \\
(1.14)\end{array}$ & $\begin{array}{r}4,024 \\
(57.3)\end{array}$ & 8 \\
\hline
\end{tabular}

写真 2 引張り破断状況

表 2 試験片の機械的性質

（）は橪準编差 $\sigma$ 


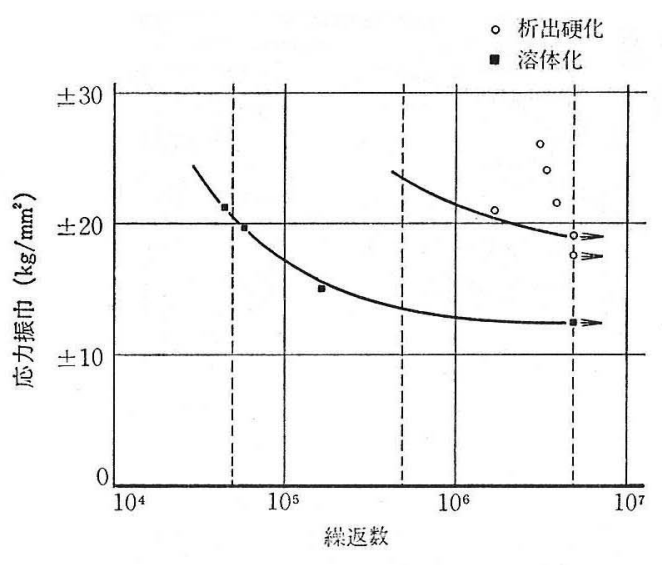

図 3 片振り $\mathrm{S}-\mathrm{N}$ 線図

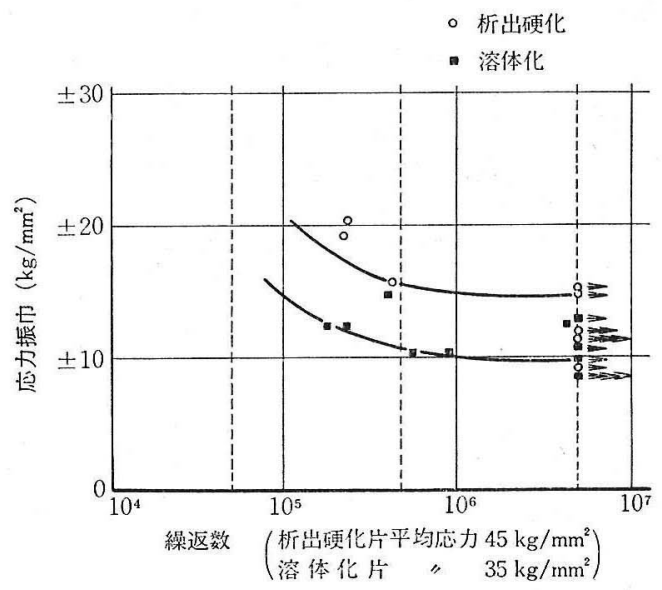

図 4 部分猳り $\mathrm{S}-\mathrm{N}$ 總四

\section{5. 考 察}

\section{1 機械的性質}

試験材は溶体化状態では体心立方構造の $\beta$ 相で，析出 硬化処理により微細な粒子が析出する，析出粒子は二次 ソルバイト状であるが, 結晶粒界は明確に観察され，腐食 液により短時間に腐食される．機棫的性質はこの $\alpha$ 粒子 の析出により増大し， $125 \mathrm{~kg} / \mathrm{mm}^{2}$ を得たが本合金は硬

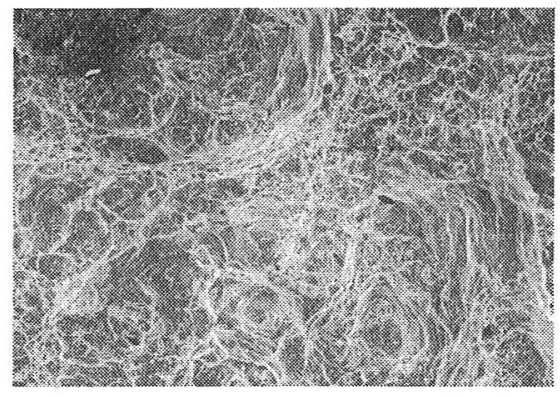

溶体化試験片 $\overrightarrow{50 \mu}$

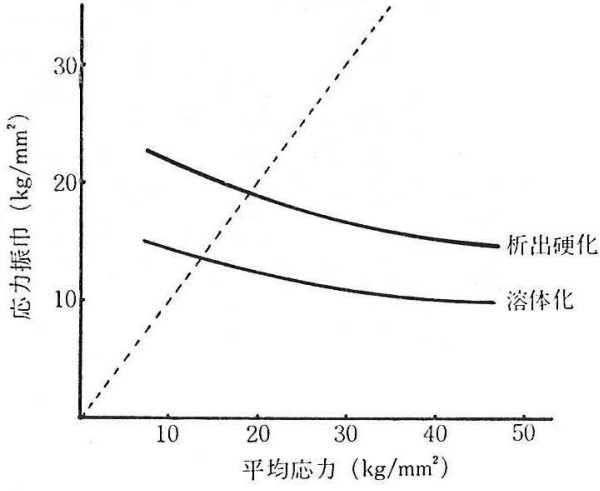

図 5 疲れ郎度線図

化後の引張強さ $140 \mathrm{~kg} / \mathrm{mm}^{2}$ 以上と言われており や低い特性值であった，乙の原因としては試験片の結晶 精度が粗いととが考えられるが，さらに熱処理条件に問 題があったととむ推察される。すなわち，硬化後は延性 が失なわれ，引張試験で局部絞りがほとんど見られない 破壤様式を示している4 . 写真 3 の走查電子影微鏡に認 められるように溶体化処理状態では多数の大きなディン プルがー面に観察されるが，析出硬化後は脆性的な粒界 破面が多数みら机，細かなディンプルとが混在する破面 を呈し，脆化している.

一方ねじり強さは析出硬化処理により大きく向上して いるが引張特性とほぼ同様の傾向を示している。

横弾性係数は析出硬化前㣪で大きく变化し，一般のば ね鋼には見られない特性である，チタン合金の同種のデ 一タが無いので比較できないが, 縦弾性係数は硬化前後 で本結果と同様に変化しておうゔ〉 チタン合金の特性と考 元られる.しかし，一般のばね材に比較して值が小さい こと, 熱処理前後で大きく変化することはば素材とし て利用する場合注意する必要がある.

\section{2 疲れ特性}

析出硬化処理により疲れ強さは向上したが, 静的な強 度加ら比較するとやや低い疲れ特性であった，疲れ破面 はばね鋼などと比較すると粒が粗く, 試験片の結晶粒度

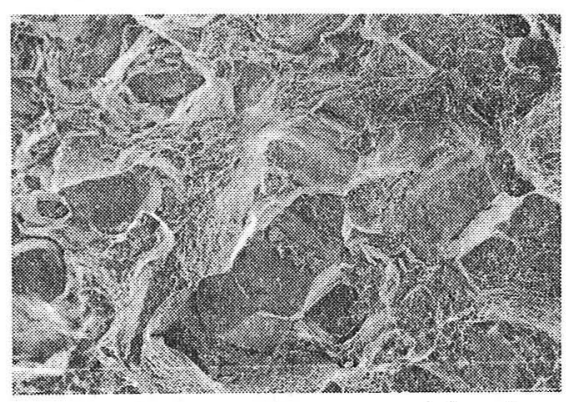

析出硬化試験片 $\quad \overrightarrow{50 \mu}$ 


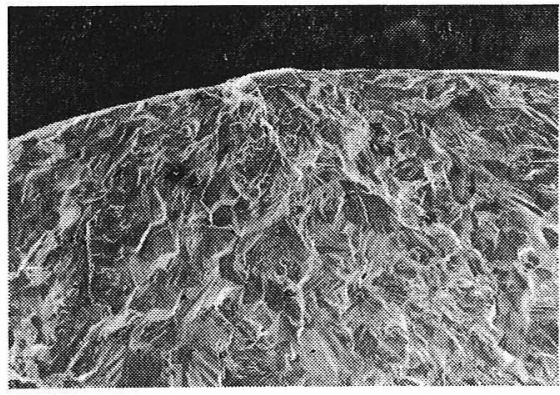

溶体化試験片 $\overleftarrow{200 \mu}$

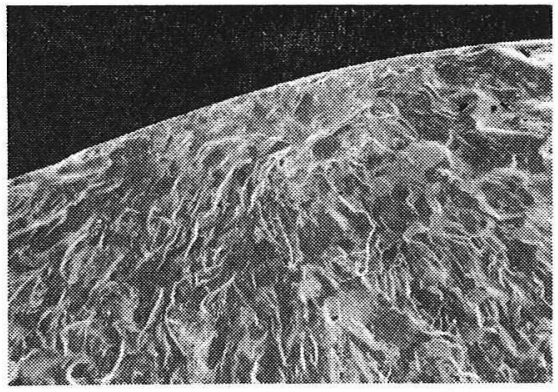

$\overleftarrow{200 \mu}$

写真 4 S.E. M 疲学破面写真

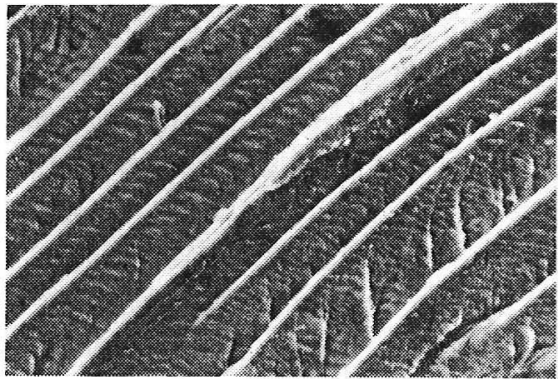

溶体化武験片

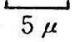

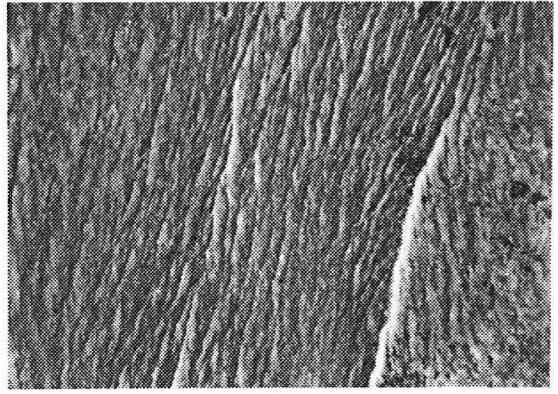

析出硬化試験片

$\breve{5 \mu}$

写真 5 S.E.M 疲労破面写.真

あ影響しているものと思われる．溶体化試験片と析出硬 化試験片の疲れ破面を走查電子顕微鏡で観察すると写真 4 亿示すようにどちらあ壁開破壊を示して扬り，特に硬 化片には痏労破面特有のストリエーションがほとんど見 られず，高倍率の写真 5 にあステップがあまり観察され ない，溶体化片，析出硬化片ともに疲れ強さがやや低い 原因としては結晶粒度が粗大であることの他に熱処理条 件が考えられる. 特に析出硬化条件については $\omega$ 脆性, 過時効から脆化しやすいので，今後ての点についてさら に検討してみる必要がある.

\section{6. あとがき}

チタン材料をばね材料として利用する場合にはその比 強度と耐食性の点であり，特にチタン合金を用いる場合 には比強度が高いととが大きな特長である，今回の試験 材ではまだ十分な特性は得られなかったが，今後さらに 今回の問題点を検討するなら, 特殊環境下でのばね素材 として，あるいは重量軽減の長所を発揮することは十分 可能と思われる，ピーニング，表面硬化処理などにより 疲れ強さを向上することも可能であるう。

ばね素材として新らしい $\beta$ 型チタン合金について機械 的性質之疲れ強さについて試験を行ったが，その結果を まとめると次の通りである.
（1）機械的性質は引張強さ $125 \mathrm{~kg} / \mathrm{mm}^{2}$ を硬化後 得ることができ，従来のチタン材料に比較してかなり高 い值を示すととがわかった，しかし，本合金はさらに高 い強度が得られると言われて扔り，乙れは本試験片の結 晶粒度が粗大であったとと，およご熱処理により脆化し たことに起因していると思わ机る。

（2）横弾性は硬化後平均 $4,204 \mathrm{~kg} / \mathrm{mm}^{2}$ で，一般 のばね鋼に比較するとかなり小さく，熱処理前後で大き く変化することがわかった。

(3) 疲れ強さは析出硬化処理により片振りで \pm 19 $\mathrm{kg} / \mathrm{mm}^{2}$, 部分片振りで $\pm 15 \mathrm{~kg} / \mathrm{mm}^{2}$ の疲れ限度を有 するととがわかった，しかし，静的強度から比較すると やや低い特性值であり，試験片の結晶粒の粗いとと，熱 処理による脆化が疲れにあ影響しているものと思われ る。

\section{文 献}

1) Robert A. Budington, SPRING, 8-1 (1972), 39

2) 大谷・西垣, 日本金属学会誌, 36-1 (1972), 90

3) 大谷・西垣，日本金属学会誌，36-4 (1972)，346

4) A. Gysler ら, ACTA METALLURGICA, 22-July (1974), 901

5) Battele Columbus Laboratories, Beta Titanium Alloys, (1972) Metals and Ceramics Information Center 